\title{
Pastoral challenges experienced by the Biblical character Job and a brief 'Theology of Suffering'
}

\author{
Xolisa Jibiliza \\ Centre for Theology and Religion \\ University of Fort Hare, South Africa \\ E-mail: xjibiliza@yahoo.com \\ DOI: 10.46222/pharosjot.1028
}

\begin{abstract}
In this paper the researcher investigates the pastoral challenges experienced by the biblical character named Job. The main message of the book of Job is the theme of theodicy or why do bad things happen to good people. The central inquiry of theodicy is to clarify how an omnipotent, omnipresent and omniscient God allows bad things to transpire in the world and this applies equally to those in anguish or to those observing suffering. In times of suffering, Jews and Christians alike may turn to the Book of Job where God permits Satan to test Job. Satan submits that Job would not adore God if God did not defend him. This research paper also sought to sight challenges encountered by Job with their description and analysis in the light of Job's faith in God. The research critiques the various pastoral care interventions offered to Job by different characters in this book of Job. Finally the researcher develops a theology of suffering and he focuses on this in the conclusion.
\end{abstract}

Keywords: Pastoral care, faith, grief, counselling and theodicy.

\section{Introduction}

The Book of Job is a literary work of art and offers us a thoughtful discussion on the suffering of a just man. 'lì $\beta$ is the Greek name of the book and it is the first book of the Wisdom Literature of Hebrew Scripture, followed by Psalms, Proverbs, Ecclesiastes, and the Song of Songs. The date the book was written is unknown. The prose Prologue (Chapters One and Two) and the Epilogue (42:7-17) describe the experience of a just man tested by misery and then restored. The first thing the Bible tells us about Job is that he was virtuous and devout, "blameless and upright," a man who "feared God and shunned evil" (Job 1:2). Job was also very wealthy. We also know from Holy Scripture that Job was a man who was momentously tested by God and even more significantly sanctified by God. He is referred to as one of the prophets of the Gentiles (Jewish Encyclopedia, 1906). Job is presented to us as a respectable and affluent family man who is tormented by Satan with God's permission with dreadful tragedies that take away all that he holds dear, including his children, his health, and his property. He battles to figure out why he is beset by tragedies and begins a pursue answers to his problems (Job 42). The Hebrew Book of Job begins with an overview of Job's character. $\mathrm{He}$ is labelled a blessed man who lives virtuously in the Land of Uz. Job was a man seriously tried by God and even more importantly blessed by God. Christianity takes on the Book of Job as canon in its Old Testament. Job is also mentioned in the New Testament of the Christian in the Epistle of James (James 5:11) which describes Job as an illustration of patience and tolerance in suffering.

Throughout the book, Job, his wife, and his friends venture to ascertain on why he, a righteous man, suffers. Job blames God of being unjust and not operating the world according to principles of impartiality. Job's friends believe that his iniquity caused his suffering. Job chooses to talk directly to God who reminds him that the world has order and exquisiteness but is also desolate and hazardous. So while does not continually know why one may suffer, 
one can bring their pain and grief to God and trust that $\mathrm{He}$ is wise, benevolent and all-knowing. Job is a man of boundless virtue, showing us optimism, endurance and persistence. "Is not your fear of God your confidence, and the integrity of your ways your hope?" (Job 4:6). The expression "patience of Job" comes from the New Testament Book of James 5:11 - "You have heard of the patience of Job, and you have seen the purpose of the Lord, because the Lord is compassionate and merciful." The Greek word úmopovì has also been translated as persistence, courage, and durability.

The Lord's approval of Job prods an angel with the title of "satan" ("accuser") to suggest that Job served God simply because God protected him. God takes away Job's protection and gives consent to the angel to take his wealth, children, and physical health, but not his life. Despite his difficult situations, he does not blaspheme God, but instead he curses the day of his birth. He does not accuse God of injustice. Job's unhappy earthly state is basically God's will. Job deliberates with three of his friends regarding his state. His friends "Eliphaz the Temanite, Bildad the Shuhite and Zophar the Naamathite," hear about his unlikely mishaps, and visit him to "comfort him," but they find him almost unrecognizable, and they then decide sit on the ground with him for a week not talking because his suffering is so huge (Job 2:1113). Discussing it with his friends did not help. Clearly, Job needed to talk it out with God Himself. "I desire to speak to the Almighty and to argue my case with God" (Job 13:3). They debate whether it was justified, and they suggest solutions to his problems. Job finally condemns all their advice, opinions, and analyses of him as a false person.

God appears to Job and his helpers out of a whirlwind, not responding to Job's fundamental questions. Job remains silent before God, and he says he appreciates that his condition is God's will even though he anguishes at not knowing why. Job seems faithful without unswerving knowledge of God and without demands for singular consideration from God. Job 28:28: "And unto man he said, Behold, the fear of the Lord, that is wisdom; and to depart from evil is understanding". God reproaches the three friends and gives them instructions for the remission of their sins, trailed by Job being reinstated to an even improved condition than he was in (Job 42:10-17). Job is blessed to have seven sons, and three daughters (Coogan, 2009).

Job finally has a discussion with God who reminds him of His eternal nature, supreme control, wisdom, divinity, authority and power over all of creation (Job 38-41). Job replies: "I know that you can do all things, and that no purpose of yours can be thwarted. "Who is this that hides counsel without knowledge?' Therefore I have uttered what I did not understand, things too wonderful for me, which I did not know" (Job 42:1-3). God then reinstated his riches and even gave him twice as much as he had before," (Job 42:10). God restored Job's fortune with "14,000 sheep, 6,000 camels, 1,000 yoke of oxen, and 1,000 female donkeys" (Job 42:12). God also re-established Job's family with seven sons, three daughters, and four generations of grandchildren (Job 42:13-16) and he had longevity as well: "And Job died, an old man, and full of days" (Job 42:17). Some Jewish bible commentators and various researchers and intellectuals highlight that Job "insists on a divine hearing in his lifetime" (Brettler, 2014).

\section{Challenges that Job experienced}

Loss: In the book of Job we are told that Job lost all his belongings (Job 1:14-17). And again we are told that Job's children were eating and drinking wine in their oldest brother's house and suddenly a great wind came from across the wilderness and struck the four corners of the house, and fell on them killing all of them (Job 1:18-19).

Description of 'Loss': Loss is defined as having something or someone leave or be taken away from you, a feeling of grief when something is gone (Anon., 1999). There is a lot of damage that happens in a person emotionally when loss strikes especially when the reality of not getting back what you lost strikes home. And because of this what we call grief is likely to 
happen and when a person is grieving there is suffering that $s /$ he encounters. Suffering on the other side weakens our rationality and lead us to total despair (Tham, 2013, p. 83). In the view of some, as much as people do suffer, they suffer uniquely moreover they respond differently to suffering.

Analysis in the light of his faith in God: The book of Job teaches us that each client is unique. The one who suffers is in this sense the master from which caregivers can learn a great deal. The sick, the handicapped, the afflicted can have something special to offer to the healers and to the world. When Job's friends and wife talk to him showing sympathy in turn, Job shows that he is not angry with God and instead he commits to praise God's name regardless of what He allowed to happen to him.

Grief: The grief that Job endures was the result of the things that occurred in him.

Description of Grief: Grief is usually it is a process, in which various emotional needs and responses are experienced over a period of time, perhaps a few weeks, but for most people many months or even years (Taylor, 1983, p. 222). Being depressed is the inclination we suffer when we have a misfortune or diverse change in our life. It is difficult for some to express and we are unique and so we experience and express being in pain and suffering in general, differently. When you understand you are in this despondency, the following stage is to locate yourself and that can be frightening and agitating for other people and sometimes those that are close to you. Communicating these feelings is the way to locate a little bliss every day and that is a process.

Sickness: Excruciating sores (Job 2:7). So Satan went out from the presence of the Lord and afflicted Job with painful sores from the soles of his feet to the crown of his head (Job 2:7).

Description of Job's sickness: Satan unleashes his second sortie against Job afflicted Job with a terrible disease (Job 2:7-8). From the various descriptions of Job's disease in the book (Job 2:8; 7:4-5; 13:14; 13:28; 16:16; 16:8; 17:1; 19:20; 19:26; 30:17; 30:30). It has been firmly observed that this was not just "boils" but rather an instance of Black Leprosy. We know that this disease changed Job's physical appearance because his friends were not able to recognize him (Job 2:12). Not a single part of Job's body was unaffected by this disease. The text says that he was infected from the soles of his feet to the crown of his head. Not a single part of him could find rest from this disease (Job $3: 26 ; 30: 17$ ).

False accusation: The main inquiry that can be tended to is whether God is noble, on the off chance that he intercedes by any means, in the event that he at all regards his creatures, man. Actually, the three friends and his wife talked false about God without insight. They do not consider God to be, He truly is, yet just observe their own conclusions and mentalities toward God. Moreover it isn't Job who has caused the enduring itself, but God. God has annihilated him and made him low. In verse 22 it is said that Job did not sin nor charge God with wrong (Job 1:22). Yes I do understand that it may happen that they were all in distress and if it so they therefore reacted wrongly to their distress.

Analysis in terms of Jobs faith in God: According to Vogels, the main question in the book of Job is not why a good God would allow suffering, but how to address God when there is suffering (Vogels, 2001, p. 995). After Job realised that he lost everything it is said that in all this, Job did not sin by charging God with wrongdoing (Job1:22).

Job is an example of how the righteous are not immune to pain and suffering. In the New Testament, James refers to Job as an example to Christians who are under distress. Brethren should look up to the prophets who talked in the Name of the Lord. We must count on those favoured who persevered such as the saints and the Laos tou Theou (Nicolaides, 2010). The Lord is our good shepherd and He will never leave. He walks with us through the dark dangerous valleys and He restores our soul when we are weary. He leads us to the path of virtue when we have lost our way and gives us bravery when we are terrified and he comforts 
us when we are broken-hearted. Christ is there for us in every challenge in life (Nicolaides \& Willimus, 2019).

We have known about the persistence of Job and have seen the result of the God's favour upon him, and that the Lord is filled with empathy and is forgiving. Most men would react to this circumstance by accusing these shades of malice for God's non-intervention. Be that as it may, Job indicated calmness in seeing God. He tore his robe, shaved his head, fell down, and worshiped God (v. 20). I like Job's response in his turmoil when he just said 'Naked came I out of my mother's womb, and naked shall I return thither: the Lord gave and the Lord has taken away; blessed is the name of the Lord. After the majority of the misfortunes that had come to pass for Job, he never made unfair claims to God and Job show a concern if we should accept only good from God and not accept evil (Job 2:10). After asking questions to God he still could reach a point where he confessed that after death he would see God as his Redeemer (Job 19:25-27).

\section{Pastoral interventions}

His wife although she did not understand him: The wife could not understand the situation instead she was blaming Job and expecting him to provide as a man and a husband. I can also say that she was also in grief because she also encountered all what affected Job like losing children because they were her children as well. Sifo (2014:15) sees pastoral care as the healing ministry that ought to bring healing to the victims that are wounded. So for me this shows that as much as this woman was there for his husband he was also wounded and as such she also needed pastoral care but unfortunately the attention was given to Job.

\section{Pastoral Care from his friends}

His friends offered the ministry of presence which is one of the very important things for a person that is having a problem. Job's friends made a trip to meet him and advise him. They could have remained at their own home and petitioned God for their friend. Rather, they relinquished time for their friend. I am certain they left their work and families behind and spent their own cash to make a trip from their respective places to be with Job during his stressful time.

One of the functions of Pastoral Care is healing and it involves healing of the mind, body and soul and so those are the things that were expected from Job's friends and his wife. Clebsh (1967) argued that healing is that function in which a representative Christian person helps a deliberated person to be restored to a condition of wholeness, on the assumption that this restoration achieves also a new level of spiritual insight and welfare. I believe that coordinating the truth of ailment into the existing history of a patient should be a huge peaceful consideration issue and should be exercised with lowliness and affection whenever done and in agreement. When offering counselling you must allow a person to show that $s /$ he needs intervention. You can't enter in a therapy to sympathise but instead you rather be compassionate.

Job's friends and wife were providing the correct therapy for being present but did the wrong thing in judging Job. Again another duty of pastoral care is sustaining one, as it consists of helping a hurting person to sustain him or herself under the circumstances they face whereby they seek to restore the person to their former condition (Clebsch, 1967, p. 8). Although they offered the ministry of presence, when they started intervening they accused Job. This was surely incorrect for them to do because God told Satan that there is no one on earth like Job, he is blameless and upright, a man who fears God and shuns evil (Job 2:3).

One of his friends named Zophar said that "...if iniquity is in your hand, put it far away, and do not let wickedness reside in your tents. Surely then you will lift up your face without blemish; you will be secure, and will not fear.... Your life will be brighter than the noonday" (Job 11:14$15,17)$. Kushner even shares his thoughts that there might have been originally a page in which his friends and his wife tell him that God does not deserve his loyalty if God can treat 
him like this, and Job rebukes them as well (Kushner, 2012, p. 26). The relationship between sin and punishment is a constant theme in the Bible and I am convinced that is another reason for them to think like this. Job showed that he needed help and did the right thing of not cursing God as his friends may thought that we would, but instead chose to curse the day that he was born (Job 3:2-40).

\section{Self-Counselling}

Self-compassion is defined by Yarnell and Neff (2012) as how "one' is emotionally supportive toward both the self and others when hardship or human imperfection is confronted." This approach certainly relates to trauma and illness is not unlike the "self-forgiveness" aspect that research aligns to current cognitive therapy (Yarnel, 2012, p. 151) . I can say Job was the therapist himself, because although his friends were there for him instead Job counselled them. It is not unusual for serious illness to cause a person to reflect on his or her life and how it's been lived. Often such an appraisal is discouraging, and causes the person to live differently in the case that they recover from their illness. In my experience with end of life care, serious illness at the end of life routinely raises these kinds of reflections, and we regularly tell family members and caregivers that addressing these spiritual questions is central, not peripheral, to effective end-of-life care (Scott, 2006).

The Book of Job asks the question, 'Why do bad things happen to good people?' Why would God, in all of his omnipotence and righteousness, cast evil upon those who devote every aspect of their life to adhering to the word of the divine? After a just and humble Job has everything he ever valued in life stripped away from him, he is left begging for an answer to this question. Within Job's struggle throughout the story, he is confronted by a number of third parties who are particularly eager and resolute in their views on this matter. But I like his response that shows the firmness of his faith in God in the midst of his tribulations. I share the same sentiments with Moyo when he says that Job has never been in any doubt that God is in control or that God is powerful; he has experienced in his body the effects of God's control and power (Moyo, 2015, p. 121). God is the creator of the universe and we see in Job 1 that nothing came into the life of Job which did not initially go through the hands of his caring God.

\section{Theology of Suffering}

The theology of suffering is also known as theodicy. As defined by Plantinga, Theodicy is the "answer to the question of why God permits evil". Theodicy is defined as a theological construct that attempts to vindicate God in response to the evidential problem of evil that seems inconsistent with the existence of an omnipotent and omnibenevolent deity (Plantinga, n.d.). The question that I wish to pose is whether theodicy, from the purpose of re-assessment of heavenly secret, can give knowledge and important responses to human anguish and pain. Generally for me Job is to see the goodness of God in the midst of suffering. Hille (2004) says that the phenomenon and meaning of suffering and its relationship to an omnipotent God has become increasingly debatable. God accepts a meek and apologetic heart. In Job 42, we see Job surrender to God and repent and he recognized that God is the creator and he is just his creation.

Theodicy that is excessively aspiring, guarantees that torment just occurs because of explicit disasters, risks, unconcerned dreadful misery and evil. C. S. Lewis, from the viewpoint of a Christian apologist, also tries to reconcile how a good, loving, and all powerful God can permit suffering (Lewis, 1940). This interpretation of theodicy is popular among Christian thinkers because it places God firmly on the throne as the controller of all creation. This viewpoint is not strictly a theodicy because real theodicy attempts to show that an all-good and all-powerful God can exist despite the prevalence of evil and suffering in the world (Newton, 2003, p. 40). Theologians and philosophers have for centuries debated the reality of evil and suffering and also the existence of an omnipotent and omnibenevolent God. One theodicy after the other 
seeks to reconcile the reality of suffering and evil with the presence of an omnipotent God. Theodicy can be defined in a national or a social religious way (Berger, 1967, p. 146).

\section{Conclusion}

The book of Job opens by telling us that Job was a righteous, decent man who was in awe of God and turned away from evil. Job's suffering did not come because he was wicked but rather because of his steadfast faithfulness to God (Job 1:8) When one suffers it is a means for God to exhibit His power and magnificence. Often in life, we find it is the righteous who suffer and the wicked who flourish. "Why do the wicked live, reach an old age, and grow mighty in power? They spend their days in prosperity, and in peace they go down to Sheol. They say to God, 'Depart from us! We do not desire the knowledge of your ways. What is the Almighty, that we should serve him? And what profit do we get if we pray to him?'” (Job 21:13-15). In Job chapter 13 he states: "Though he slay me, I will hope in him." No one and nothing can take away our contentment or peace when our hope is in God. We must never lose our confidence in God. Mary was the most blessed of women, and the perfect model of obedience to the will of God and all of us, man or woman must be obedient to God as she was, He is our Lord and Master (Nicolaides, 2014).

Jesus tells us in Matthew 6:25-34:

25 "'Therefore I tell you, do not be anxious about your life, what you will eat or what you will drink, nor about your body, what you will put on. Is not life more than food, and the body more than clothing? ${ }^{26}$ Look at the birds of the air: they neither sow nor reap nor gather into barns, and yet your heavenly Father feeds them. Are you not of more value than they? ${ }^{27}$ And which of you by being anxious can add a single hour to his span of life? ${ }^{28}$ And why are you anxious about clothing? Consider the lilies of the field, how they grow: they neither toil nor spin, ${ }^{29}$ yet I tell you, even Solomon in all his glory was not arrayed like one of these. ${ }^{30}$ But if God so clothes the grass of the field, which today is alive and tomorrow is thrown into the oven, will he not much more clothe you, $\mathrm{O}$ you of little faith? ${ }^{31}$ Therefore do not be anxious, saying, 'What shall we eat?' or 'What shall we drink?' or 'What shall we wear?' ${ }^{32}$ For the Gentiles seek after all these things, and your heavenly Father knows that you need them all. ${ }^{33}$ But seek first the kingdom of God and his righteousness, and all these things will be added to you. 34 "Therefore do not be anxious about tomorrow, for tomorrow will be anxious for itself. Sufficient for the day is its own trouble".

Ultimately, God rewarded Job for his devout faithfulness.

The concluding observation is that it is necessary to examine a variety of different views on theodicy. Among other things the collection of viewpoints and philosophies show that theodicy revolves around God and His relationship with His creation. Regardless of how extreme an initial problem is, we ought to never expect that God isn't tuning in or couldn't care less. He is omnipotent, omniscient and omnipresent. He sees exercises we have to discover that are past our present limited human comprehension. We need to dependably recall some amazing guidance from King David and 'wait on the Lord, be of good courage, and God will reinforce your heart.' Or else we ought to gain from Job's understanding to keep up being patient, and regard and trust in God even amidst our sufferings. One day in the near future we will see with our own eyes our Redeemer Christ who lives today and eternally and because He does live we are in a position to face all that life can throw at us. Humility is the significant aspect required by us. Pride can inhibit us by clouding our vision and Job elucidates: 'Behold, the fear of the Lord, that is wisdom, and to turn away from evil is understanding' (Job 28:280. 


\section{References}

Berger, P. (1967). The Sacred Canopy: Elements of a Sociological Theory of Religion. Garden City: Doubleday.

Brettler, M. Z. (2014). The Jewish Study Bible. [S.I.]: Oxford University Press. p. 1523

Clebsch, W.A. \& Jaekle, C.R. (1967). Pastoral care in historical perspective, an essay with exhibits, New York: Harper \& Row.

Coogan, M. B. (2009). Job's Wife and Daughters. Oxford University Press. p. 388.

Eichrodt, W. (1983). Faith in providence and theodicy in the Old Testament. In Crenshaw, J.L., ed. Issues in Religion and Theology, Philadelphia: Fortress.

Hille, R. (2004). A Biblical-Theological Response to the Problem of Theodicy in the Context of Modern Criticism of Religion. Evangelical Review of Theology, 28(1), 21-37.

Jewish Encyclopedia. (1906). Available online at: Jewish Encyclopedia.com. https://www.jewishencyclopedia.com/ Retrieved 11 February, 2020).

Kushner, H. (2012). The Book of Job When bad things happened to a Good person. New York: Schocken Books.

Moyo, H. (2015). Pastoral Care in a Globalised World: african and European Perspectives. Pietermaritzburg: Cluster Publications.

Newton, A. (2003). A Study and Critique of Various Theodicies. Faith \& Mission, 20(3), pp. 23-46.

Nicolaides, A. (2010). 'The Laos tou Theou - an orthodox view of the "people of God"', HTS Teologiese Studies/Theological Studies, 66(1). DOI: 10.4102/hts.v66i1.372

Nicolaides, A. (2014). The philosophical conception of Mariology, Phronimon, 15 (2). Available online at https://journals.co.za/doi/pdf/10.10520/EJC167268

Nicolaides, A.C. \& Willimus, K. (2019). The Crucifixion of Christ in its milieuand its spiritual significance today, Pharos Journal of Theology, Volume100. Available online at https://www.pharosjot.com/uploads/7/1/6/3/7163688/article_20_vol_100_2019_greek_orthod ox_archdiocese.pdf

Plantinga, A. (n.d.). Theodicy-Wikipedia. [Online] Available at: http://en.m.wikipedia.org [Accessed 4 May 2020].

Scott, B. R. (2006). On the ConnectionBetween Sickness and Sin: A Commentary, California: Biola University.

Sifo, L.G. \& Masango, M.J. (2014). The mind of spousal violence on the children: A pastoral care approach. HTS Teologiese Studies/Theological Studies, 70(2). Available online at http://dx.doi.org/10.4102/hts.v70i2.2044.

Taylor, H., 1983. Tend My Sheep. Cambridge: Univeristy Press.

Tham, J. (2013). Communicating with sufferers: Lessons from the Book of Job. In: Lessons from the book of Job. Rome: Oxford University Press, pp. 82-99.

Vogels, W. (2001). Giobbe.L'uomo Che ha Parlato Bene di Dio. Italy: Edizioni San Paolo. 
Pharos Journal of Theology ISSN 2414-3324 online Volume 102 - (2021)

cc) (i)@( $)$ Copyright: @2021 Open Access/Author/s - Online @ http//: www.pharosjot.com

Yarnel, L. \&. Neff, K.D. (2012). Self-compassion, innterpersonal conflict resolutions, and wellbeing. Self and ldentity, 12(2), 146-159. 